\title{
ПРИНЦИП СТУПЕНЕВОСТІ В СУЧАСНІЙ МЕТОДИЧНІЙ ПІДГОТОВЦІ МАЙБУТНЬОГО ВЧИТЕЛЯ СУСПІЛЬСТВОЗНАВЧИХ ДИСЦИПЛІн
}

\footnotetext{
Автор актуалізує проблему ступеневої методичної підготовки вчителя суспільствознавчих дисииплін в контексті напрачювання нової нормативно-правової бази в галузі вищої педагогічної освіти Украӥни. Висловлює думку щьодо важливості врахування принципу ступеневості у формуванні змісту освітньо-кваліфікаиійних рівнів та модернізації навчальних планів і оновленні робочих програм.

Ключові слова: принцип ступеневості, ступенева освіта, бакалавр, магістр, методична підготовка, вчитель суспільствознавчих дисциплін.
}

Автор актуализирует проблему уровневой методической подготовки учителя обществоведческих дисииплин в контексте наработки новой нормативно-правовой базы в отрасли высшего педагогического образования Украины. Выражает мнение относительно важности учета принципа уровней в формировании содержания образовательноквалификаиионных уровней и модернизачии учебных планов, обновлении рабочих программ.

Ключевые слова: принцип уровней, уровневое образование, бакалавр, магистр, методическая подготовка, учитель обществоведческих дисциплин.

An author does actual the problem of level preparation of teacher in the context of work of new normatively legal bases in industry of higher pedagogical education of Ukraine, expresses opinion to competence-based approach in realization of methodical preparation of teacher.

Key words: actual preparation, education of levels, bachelor, master's degree, methodical preparation, teacher of social science disciplines.

Модернізація методичної підготовки вчителя суспільствознавчих дисциплін нині є однією 3 актуальних проблем вищої педагогічної школи, оскільки від неї залежить майбутній світогляд випускників навчальних закладів. Її розв'язання залежить від логіки, наступності й системності змісту суспільствознавчої освіти й відповідної методичної підготовки, що закладений умовами ступеневої освіти в освітньо-професійні програми, навчальні плани та робочі програми дисциплін. Відповідно до цілей, спрямованих на інтеграцію в єдину європейську спільноту, оновлення змісту української вищої педагогічної освіти має відбуватися 3 урахуванням загальноєвропейських тенденцій [12, с. 6 - 7].

Принщип ступеневості є фундаментальним принципом професійної підготовки педагогів у країнах, які приєдналися до Болонського процесу. Його правові витоки слід шукати в низці важливих європейських документів: Великої Хартії Університетів (1988р.), де проголошувалася прихильність університетів до європейської гуманістичної традиції, Лісабонської конвенції (1997р.) про визнання кваліфікацій для системи вищої освіти європейського регіону та Сорбонської декларації (1998р.) [1] щодо узгодження структури вищої освіти.

Предметами дослідження у вітчизняній педагогічній науці в останні роки ставали методологічні основи ступеневої професійної підготовки фахівиів у системі неперервної освіти (С. Гончаренко, І. Зязюн, В. Кремень, Н. Ничкало); порівняльний аналіз ступеневої освіти (В. Козаков, Т. Кошманова, Л. Пуховська); проблема наступності (В. Бондар, О. Галус, Р. Гуревич, Ю. Зіньковський, А. Кухта, В. Манько, О. Мороз, В. Мадзігон, Н. Ничкало, В. Сухомлинський, В. Шморгун); аналіз історичного досвіду минулого України щодо підготовки майбутнього вчителя (А. Алексюк, Н. Дем'яненко, Т. Завгородня, М. Свтух, В. Курило, І. Курляк, В. Майборода); теоретичні засади підготовки майбутніх учителів (Є. Барбіна, В. Бондар, А. Глузман, О. Дубасенюк, Н. Кічук, О. Пєхота, С. Сисоєва, Г. Троцко).; предметне наповнення змісту шкільної суспільствознавчої освіти (Т. Бакка, К. Баханов, Н. Гупан, О. Пометун, І. Смагін, О. Турянська Г. Фрейман та ін.) та методологічні підходи до методичної підготовки вчителя суспільствознавчих дисииплін в умовах магістерської освіти (К. Баханов).

Метою статті $є$ актуалізація принципу ступневості в методичній підготовці вчителя суспільствознавчих дисциплін в контексті напрацювання нової нормативно-правової бази в галузі вищої педагогічної освіти України, пошуку наукових підходів до його ефективної реалізації.

На законодавчому рівні зміст ступеневості обгрунтовувався в Законі України «Про освіту» (стаття 30, п. 2) в редакції 1996 року [8, с. 253 - 278], на основі якого було прийнято: Закон України «Про вищу освіту» [5], затверджені Постанова Кабінету Міністрів України № 507 «Про перелік напрямів та спеціальностей, за якими здійснюється підготовка фахівців у вищих навчальних закладах за відповідними освітньо-кваліфікаційними рівнями» [10], Постанова Кабінету Міністрів України № 65 «Про затвердження Положення про освітньо-кваліфікаційні рівні (ступеневу освіту)» [8, с. 375 - 381], Національна програма «Вчитель» [13] й Постанова Кабінету Міністрів України № 787 від 27.08. 2010 р. «Про затвердження переліку спеціальностей, за якими здійснюється підготовка фахівців у вищих навчальних закладах за освітньо-кваліфікаційним рівнями спеціаліста і магістра» [7]. 
Запровадження ступеневої вищої освіти в Україні значно розширило правові рамки фахівців, про що свідчить ратифікована Верховною Радою України конвенція «Про ратифікацію Конвенції кваліфікацій з вищої освіти в Свропейському регіоні» (Лісабон, 1997 р.) [11]. Учасники Болонського форуму (1999р.) схвалили двоетапну систему вищої освіти, зазначаючи, що введення подібної системи бажане в європейських країнах.

Саме 3 другої половини 90-х рр. минулого століття розпочинає формуватися зміст сучасної методичної підготовки вчителя суспільствознавчих дисциплін. Поява в середній загальноосвітній школі дисципліни «Народознавство», зумовила внесення відповідних змін у методичну підготовку вчителя історії - «Методика викладання народознавства» й відповідну появу нової спеціальності «вчитель історії та народознавства». Змістової й структурної модернізації в цей період зазнала методична підготовка вчителя суспільствознавства, що почала формуватися з урахуванням принципу ступеневості й наступності.

Нині у вищих навчальних закладах України здобуття вищої освіти за спеціальностями здійснюється ступенево або неперервно залежно від вимог до рівня оволодіння певною сукупністю професійних компетентностей, необхідних для майбутньої професійної діяльності (Стаття 6., п. 2) [5]. Підготовка фахівців для галузі освіти регламентується статтею 7 Закону України «Про вищу освіту» й здійснюється за двома ступенями: «бакалавра», «магістра» [5].

Бакалавр - освітньо-кваліфікаційний рівень вищої освіти, який здобувається на основі повної загальної середньої освіти і передбачає оволодіння особою відповідною освітньо-професійною програмою та набуття компетентностей для виконання завдань та обов'язків (робіт) певного рівня професійної діяльності, що передбачені для первинних посад у певному виді економічної діяльності. Нормативний термін навчання за освітньо-професійною програмою бакалавра на основі повної загальної середньої освіти становить три-чотири роки [4].

Магістр - освітньо-кваліфікаційний рівень вищої освіти, який здобувається на основі освітньокваліфікаційного рівня бакалавра і передбачає оволодіння особою відповідною освітньо-професійною програмою та набуття компетентностей для виконання завдань та обов'язків (робіт) інноваційного характеру певного рівня професійної діяльності, що передбачені для первинних посад у певному виді економічної діяльності. Нормативний термін навчання за освітньо-професійною програмою магістра на основі освітньо-кваліфікаційного рівня бакалавра становить півтора-два роки [5].

Запровадження ступеневої системи вищої освіти й уведення нових освітньо-кваліфікаційних рівнів «бакалавр» та «магістр» надали широкі можливості для задоволення освітніх потреб конкретної особи, забезпечили гнучкість загальноосвітньої, загальнокультурної та наукової підготовки майбутнього вчителя, уможливили підвищення їхнього соціального захисту на ринку праці та інтеграцію у світове освітянське співтовариство.

У 2001 році набув чинності «Комплекс нормативних документів для розробки складових системи стандартів вищої освіти», де регламентовані нові вимоги до вищої освіти і відповідної підготовки фахівця, що обумовлені ідеями і принципами ступеневої освіти в Україні [3].

Актуальність розв'язання науково-організаційних проблем ступеневої методичної підготовки майбутніх учителів суспільствознавчих дисциплін зумовлена потребами практики, насамперед соціальними проблемами підвищення статусу вчителя-суспільствознавця, відповідно до здобутого ним рівня чи ступеня готовності виконувати складні специфічні педагогічні функції. Соціальний сенс полягає ще й у тому, щоб у процесі реалізації ідеї ступеневої методичної підготовки майбутнього вчителя суспільствознавчих дисциплін виявити той людський потенціал, який природно, генетично забезпечує ефективність праці вчителя-предметника, фасилітатора, вихователя, тьютора - помічника й керівника навчальним процесом, науковця-дослідника методичних проблем.

Ступенева методична підготовка вчителів суспільствознавчих дисциплін зумовлена потребою підвищення конкурентоспроможності та мобільності його на ринку праці в контексті внутрішніх (утвердження ринкових і демократичних відносин) та зовнішніх (глобалізація і становлення інформаційного суспільства) суспільних змін, що відбуваються в Україні і світі. Щорічне подвоєння обсягу суспільствознавчої інформації та наукових знань із різних наук (політичних, філософських, соціологічних, правових тощо), соціального та професійного досвіду, зміни форм педагогічної комунікації та духовно-психологічних умов життєдіяльності суспільства формують своєрідний виклик методичній кваліфікації педагога (учитель історії, учитель права, учитель етики), потребують iii модернізації. Ступенева методична підготовка майбутніх учителів суспільствознавчих дисциплін $\epsilon$ ефективною відповіддю на цей виклик, оскільки віддзеркалює особливості суспільних потреб, сучасні тенденції в педагогічній науці та суспільствознавчій освіті, зміни в стандартах загальної середньої освіти.

Неперервна програма підготовки для здобуття найвищого освітньо-кваліфікаційного рівня реалізується, як правило, у ВНЗ третього і четвертого рівнів акредитації [2, с. 4].

Запровадження ступеневої системи освіти передбачає визначення кваліфікаиійних умов вищої освіти, які досягаються в університеті засвоєнням студентом певної кількості теоретичних та практичних дисциплін протягом періоду навчання. Методичну підготовку студентів історичних факультетів/інститутів слід розглядати як систему, в якій формуються предметно-методичні 
компетентності у чіткій логічній послідовності та відповідності з функціональними обов'язками стосовно їх майбутніх посад та вимог 3 урахуванням росту потреб суспільства й шкільної суспільствознавчої освіти.

Класифікація ступенів та кваліфікацій має важливе значення, тому що їх присвоєння свідчить про важливі перехідні рубежі від системи освіти до ринку праці у межах конкретної країни/ регіону.

У контексті Міжнародної Стандартної Класифікації Занять (МСКЗ-88) «кваліфікація» визначається як здатність робітника виконувати конкретні завдання та обов'язки у рамках певного виду діяльності й має певні параметри: 1) рівень кваліфікації, який визначається складністю і обсягом завдань та обов'язків, що виконуються; 2) кваліфікаційну спеціалізацію, яка визначається певною галузю знань.

В Україні у межах діяльнісного підходу специфікація терміну «кваліфікація» змістовно більш наповнена та диференційована, ніж в Європі, але менш гнучка, оскільки відповідно до Закону України «Про вищу освіту» вища професійна освіта спрямована на певну первинну посаду.

«Професійна» кваліфікація значно ширша від «освітньої» за рахунок «набору обов'язків», де має місце звуження обсягу та складності завдань певної предметної області, які розв'язуються, оскільки необхідність і достатність обсягу та їх складності зумовлюються «обов'язками», а не визначеною глибиною вивчення предметної області. Для прикладу, виховні функції вчителя як класовода, вихователя на уроці суспільствознавчих дисциплін недостатньою мірою враховані в обсяговому й змістовому наповненні навчального плану майбутніх учителів (Навчальний план. Спеціальність: 6.020302. Історія. Спеціалізація: правознавство). Водночас, теоретико-методична й практична підготовка вчителя до викладання суспільствознавчих дисциплін завершується на рівні бакалаврату й не залишає предметно-педагогічних функцій для вчителя-суспільствознавця на рівні ще існуючого освітньо-кваліфікаційного рівня «спеціаліст» та магістратури. Випускник магістратури при працевлаштуванні практично має майже однакові права 3 випускником - «спеціалістом». Згідно із законом «Про вищу освіту» і наказом № 285, він має працевлаштовуватися на первинну посаду, яка передбачена Галузевим стандартом ОКХ підготовки.

Національна рамка кваліфікацій грунтується на принципах ієрархічності та наступності кваліфікаційних рівнів (яких установлено 10: від 0 до 9), сумісності з європейськими рамками кваліфікацій, гнучкості, прозорості та на компетентнісному підході до опису кваліфікацій [6], де компетентність постає як динамічна комбінація знань, розуміння, умінь, цінностей, інших особистих якостей, що описуються в термінах результатів навчання.

Практика реалізації компетентнісного підходу в європейських системах вищої професійної освіти в цілому виправдала очікування роботодавців та студентів в частині підвищення рівня прозорості змісту спеціальностей ВНЗ та якості освіти. Але впровадження визначило низку пріоритетних питань, які потребують розв'язання в частині: підстав для виокремлення рівнів підготовки фахівців в структурі ВН3; гармонізації навчальних планів з точки зору структури, програм і методів навчання; динаміки змін змісту навчання в залежності від змін кон'юнктури ринку праці, конкретних потреб роботодавців, регіональних особливостей. Якщо перше - розв'язується, як правило, засобами державних стандартів (рівень галузевого Міністерства), то проблема якісного і ефективного змісту освіти коригується на рівні конкретного ВНЗ.

У процесі розроблення стандартів ураховуються процеси створення єдиного освітнього простору в Європі. Рекомендації щодо нормативних вимог визначаються згідно з Лісабонською конвенцією і Болонською декларацією. Водночас аналіз ситуації у вищій педагогічній освіті України дозволяє стверджувати про існування непослідовності у змісті ступеневої освіти, дисбалансі за рівнями підготовки (бакалавр-магістр), що має своє логічне обгрунтування через відсутність сучасних державних стандартів.

У зв'язку з цим тлумачення та виконання спільних текстів стандартів і концепцій суттєво різниться у кожного ВНЗ, що призводить до якісних і кількісних відмінностей компетентностей фахівців схожих спеціальностей. Для прикладу - відсутність державних стандартів магістрів із галузі знань «Педагогічна освіта», напряму підготовки «Професійна освіта», спеціальності «Історія» (8.01010401) та стандартів магістрів із галузі знань «Гуманітарні науки», напряму підготовки «Ітсторія*» (здійснення підготовки 3 присвоєнням кваліфікації вчителя або викладача вищого навчального закладу, за умови виконання психолого-педагогічної, методичної та практичної програми підготовки відповідно до галузевого стандарту педагогічної освіти), спеціальності «Історія», (8.02030201) призвела до суттєвої різниці в змісті викладання фахових дисциплін й результатах - магістерських компетентностях майбутнього вчителя історії.

У цьому ми наблизилися до Франції, 3 яскраво вираженою політикою регіональної децентралізації, де концептуальні тексти стандартів відсутні, регіональні та відмінності між ВН3 найбільш значущі.

Поміж проблем сучасної вищої школи в Україні виділяється питання співвідношення академічної освіти, що дає можливість зростання в академічному плані, і професійної освіти, що дає можливість швидко адаптуватись на ринку праці. В цьому аспекті Україна намагається зберегти кращі традиції фундаментальної освіти й фундаментальної підготовки. 
Освітньо-кваліфікаційний рівень вищої освіти в Україні формально поєднує в програмах освіти як академічну, так і професійну спрямованість. Сьогодні це призводить до проблеми формування змісту освіти. 3 одного боку, скорочується навчальний час, необхідний для глибокого розуміння предметів соціально-економічної та природничо-наукової спрямованості (тобто для фундаменталізації освіти), 3 іншого - страждає практична підготовка майбутніх учителів, оскільки вони не отримують повноцінних навичок професійної роботи (тобто не отримують визначеного рівня кваліфікації).

Перегляд статусу кваліфікацій в українській освіті означає зміну орієнтирів: від підготовки студента до майбутнього примусового «розподілу» до нової філософії освіти, заснованої на підготовці випускника вищого навчального закладу для конкретного ринку праці. Вища школа готує випускника не до конкретного робочого місця, а до вільного пошуку роботи.

НАПН України перспективними моделями підготовки педагогічного персоналу вважає дві [4]: інтегрованого магістра (нині спеціаліст) з ранньою педагогічною спеціалізацією (у педагогічних університетах та інститутах) - традиційний для нашої системи освіти; двоциклову підготовку бакалавра - магістра з пізнішою педагогічною спеціалізацією (у класичних університетах) європейський варіант освіти.

Одним із важливих ресурсів, на основі якого можливо суттєво вплинути на процес ефективного формування професійних компетентностей майбутніх учителів суспільствознавчих дисциплін в контексті переходу на двоступеневу систему «бакалавр-магістр» та інноваційних процесів, що відбуваються в шкільній суспільствознавчій освіті, є якісно нова за змістом та формі модель системи їх методичного навчання. Однак необхідно враховувати, що орієнтація на формування методичних компетенцій студентів історичних факультетів/інститутів, їх розвиток у процесі навчання, використання їх вікових та індивідуальних особливостей не досягається за рахунок простого збільшення годин на фахові та педагогічні дисципліни чи введення спецкурсів, спецсемінарів.

Зміна парадигми вищої педагогічної освіти, моделювання її на основі врахування двоступеневої системи підготовки означає необхідність концептуального перегляду в дидактиці та навчальнопредметному забезпеченні процесу навчання студентів (навчальних планах, програмах дисциплін методичного спрямування) змісту, що дозволить формувати у майбутніх учителів необхідні професійні компетентності. Перехід вищої педагогічної школи до ступеневої системи освіти передбачає оновлення змісту базової педагогічної освіти бакалаврів-суспільствознавців, а також розроблення змісту, форм і методів педагогічної підготовки магістрів-суспільствознавців як фахівців найвищого кваліфікаційного рівня, які в майбутньому поновлять склад науковців із відповідних галузей науки, викладачів вищих навчальних закладів, спеціалізованих середніх навчальних, закладів із поглибленим вивченням суспільно-політичних предметів, гімназій, ліцеїв, коледжів та управлінський освітянський корпус.

Задекларований перехід до ступеневого навчання змінює структуру методичної підготовки вчителя суспільствознавчих дисциплін, вимагає створення нових за формою і змістом нормативних документів планування навчального процесу. Для підготовки таких учителів у системі ступеневої освіти необхідно створити спеціальну структуру навчання зі зміною характеру професійної підготовки в бік iï практичної зорієнтованості, предметно-методичного насичення, реалізацією наступності в навчальному процесі, забезпеченням взаємозв'язку суспільствознавчих і методичних дисциплін, оптимальними навчальними планами і освітньо-професійними програмами.

\section{Література}

1. Болонський процес у фактах і документах (Сорбонна-Болонья-Саламанка-Прага-Берлін) / упоряд. : М. Ф. Степко, Я. Я. Болюбаш, В. Д. Шинкарук та ін.; МОН України. - К. - Тернопіль : «Економічна думка» ТАНГ, 2003. - 60 с. - (Інтеграція вищої освіти України в європейський освітній простір). 2. Болюбаш Я. Я. Організація навчального процесу у вищих закладах освіти : навч. посібник для слухачів закладів підвищення кваліфікації системи вищої освіти / Я. Я. Болюбаш. - К. : ВВП «КОМПАС», 1997. - 64 с. 3. Комплекс нормативних документів для розробки складових системи стандартів вищої освіти. Додаток 1 до наказу Міносвіти України від 31.07 .1998 р. № 285 зі змінами та доповненнями, що введені розпорядженням Міністерства освіти і науки України від 05.03.2001 р. №28-р. // Інформаційний вісник «Вища освіта».-2003. - № 10. - 82 с. 4. Національна доповідь про стан і перспективи розвитку освіти в Україні (друге видання) / Нац. акад. пед. наук України; [авт.: В. П. Андрущенко, І. Д. Бех, М. І. Бурда та ін.; редкол.: В. Г. Кремень (голова), В. І. Луговий (заст. голови), В.М.Мадзігон (заст. голови), О. Я. Савченко (заст. голови)]; за заг. ред. В. Г. Кременя. - К. : Пед. думка, 2011. - 304 с. - Бібліогр.: с. 149 - 167. - (До 20-річчя незалежності України). 5. Про вищу освіту: Закон України від 26.12.2002 р. № 2984-ІІІ // Відомості Верховної Ради. - 2002. - № 20. 134 с. 6. Про затвердження Національної рамки кваліфікацій України: Постанова Кабінету Міністрів України. - Режим доступу : http://document.ua/pro-zatverdzhennja-nacionalnoyi-ramki-kvalifikacii-doc81930.html 7. Про затвердження переліку спеціальностей, за якими здійснюється підготовка фахівців у вищих навчальних закладах за освітньо-кваліфікаційним рівнями спеціаліста і магістра: Постанова Кабінету Міністрів України № 787 від 27.08. 2010 p. - Режим доступу : http://zakon.rada.gov.ua/ 8. Про затвердження Положення про освітньокваліфікаційні рівні (ступеневу освіту): Постанова Кабінету Міністрів від 20 січ. 1998 р. № 65 // Нормативноправові документи з питань вищої освіти [Текст] : законы и законодательные акты / Уклад.: Т. Дудник, Т. Іщенко, Н. Хоменко, за ред. Я. Я. Болюбаша. - К. : [б. и.], 2004. - 304 с. 9. Про освіту: Закон Украйни від 23.03.1996 p. № 100/96-ВР // Відомості Верхов. Ради України. - 1996. - № 21. - С. 253 - 278. 10. Про перелік напрямів та спеціальностей, за якими здійснюється підготовка фахівців у вищих навчальних закладах за відповідними освітньо-кваліфікаційними рівнями: Постанова Кабінету Міністрів України від 24.05.1997 р. 
№ 507. - Режим доступу : http://zakon.rada.gov.ua/ 11. Про ратифікацію Конвенції кваліфікацій 3 вищої освіти в Європейському регіоні: Закон України від 03.12.1999 р. № 1273-XIV. - Режим доступу : http://zakon. rada.gov.ua/ 12. Проект Національної стратегії розвитку освіти в Україні на 2012-2021 роки. Офіційне видання. К. : Видавничий дім «Букрек», 2011. - 32 с. 13. Цільова комплексна програма «Вчитель» // Освіта України. 1996. - № 64. 